ized. Other difficulties are the similarity in properties of normal and cancer cells, and the variation in growth and lethal effects of spontaneous tumours. The advantages of using a tumour which has arisen in a pure line of mice and is transplanted into mice of the same strain are stressed; no reference is made to a tumour of that nature introduced by Dr. E. Boyland some years ago.

\section{RESEARCH WORK FOR 1944 IN THE ACADEMY OF SCIENCES OF U.S.S.R.}

\section{By LYDIA BACH}

\footnotetext{
$\mathrm{T}$
} HE Academy of Sciences of the U.S.S.R., as the guiding centre for all scientific activity in the Soviet Union, has planned its work for 1944 in four main divisions. First, the study of scientific problems of various branches of knowledge for the advancement of science in general; secondly, research work in the sphere of improving armaments for the Red Army; thirdly, the mobilization of resources to strengthen the defence of the U.S.S.R. ; and, fourthly, scientific problems connected with the rehabilitation of regions liberated from the German invaders and devastated by war, and further development of the national economy as a whole.

Plans for the year's work were drawn up by each institute separately, primarily by laboratories and then for institutes as a whole. A committee from each institute selects from its programme problems which offer the greatest interest for inclusion in the general plan of the Academy. Plans are then approved at a general meeting of members of the Academy, corresponding members, and leading scientific workers of each section of the Academy, which examines the subjects submitted in detail and draws up a plan for each section of the Academy. The Academy has eight sections covering the following branches of knowledge: physics and mathematics, chemistry, geology and geography, biology, technology, history and philosophy, economics and law, language and literature.

The 1944 plan which was approved by the presidium of the Academy on December 21, 1943, shows that the Academy is devoting the greatest amount of attention to big theoretical and practical research tasks, on the assumption that other questions can be better dealt with by institutions which work in special spheres and branches of industry.

In the Section of Physics and Mathematics, cosmic rays and the structure of the atomic nucleus will be studied by Dr. A. Alikhanov and Prof. D. Skobeltsin. Expeditions to the Pamirs and Mount Elbrus are being organized to study cosmic rays at high altitudes. The building of a cyclotron has been planned. Dr. P. Kapitza and his colleagues will continue their investigation on properties of matter at temperatures approaching absolute zero. The problems of the struc. ture of matter are being worked at in the Physicotechnical Institute by Joffe, and in the Institute of Crystallography by Prof. A. Shubnikov; at the Institute of Physics, S. Vavilov is working on mechanics, luminosity and the employment of luminescence. At the Institute of Mathematics, I. Vinogradov, S. Sobolev, A. Kolmogorov and S.
Bernstein are working on theoretical mechanics and giving particular attention to methods of employing ealculating machines to solve equations arising in mathematical physics.

In chemistry, work will proceed on the development of modern conceptions of chemical bonds in the kinetics and catalysis of chemical reactions (N. Semenov, Prof. S. Roginsky). Frumkin and his school will continue their work on theoretical questions connected with electrode processes and the theory of surface phenomena. Work on the synthesis of carbon compounds of high molecular weight is proceeding. The chemical institute of the Academy of Sciences is devoting considerable attention to scientific and technical assistance to industrial enterprises, employment of new chemical and technical processes and their intensification, and also the rehabilitation economy of devastated regions which have been liberated from enemy occupation.

The programme for geology and geography includes the study of the main questions of stratigraphy and tectonies of the U.S.S.R., the mineralogy and the geochemistry of the formation and distribution of ore deposits. P. Stepanov will continue his work on the theory of coal formations in the world; $V$. Obruchev and his colleagues will work on the theoretical and practical problems connected with perpetually frozen territories. The work is being extended to the spheres of hydrogeology and the study of lakes and volcanoes. Work on the study of geography in the Soviet Union and foreign countries, and research work on processes taking place in the soil will be continued.

Each biological institute will work on its own special problems, but will handle them from the evolutionary point of view, developing them all as a complex whole in accordance with the basic problem of biology, that of Darwinism. The institute of evolutionary morphology is studying the laws governing that branch of biology. In the institute of palæontology, Borisyak has established a system of practical phylogenesis for the determination of evolutionary processes in fossils. The institute of physiology (Leon Ordeli) is concerned with the evolutionary processes of various systems of the human organism, museular, neural, etc. Trofim Lysenko, of the Institute of Genetics, is continuing his work on inheritance.

Work on the humanities includes the study of Russian history, peasantry and working class collectivization, Russian culture, patriotic war, study of Slavonic peoples and the history of international relations. Further volumes, "History, Philosophy", will cover Russian philosophy and the philosophical views of Marx, Engels, Lenin and Stalin.

The mobilization of the country's resources for the needs of defence includes the study of problems connected with the industrialization of Kazakhstan. Work on the oil of new oilfields in Bashkiria continues.

In order to help rehabilitation economy in districts that have been devastated by enemy occupation and by war in general, and to help the general development of national economy, the problem of post-war provision of electrical energy is receiving urgent attention and fundamental principles are being laid down. Research is being done on the restoration of the Donets coal basin and its coalmines; industrial enterprises and transport are being greatly extended. The Academy's institute of economies is warking on a very comprehensive publication, "Soviet Economy in the War and Post-War Periods". 